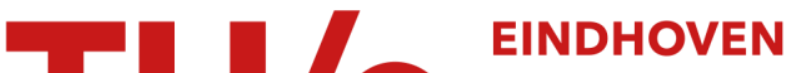

\section{Signal processing in analytical isotachophoresis using standard chromatographic integration procedures}

\section{Citation for published version (APA):}

Reijenga, J. C., lersel, van, W., Aben, G. V. A., Verheggen, T. P. E. M., \& Everaerts, F. M. (1984). Signal processing in analytical isotachophoresis using standard chromatographic integration procedures. Journal of Chromatography, 292(1), 217-226. https://doi.org/10.1016/S0021-9673(01)96204-1

DOI:

10.1016/S0021-9673(01)96204-1

Document status and date:

Published: 01/01/1984

\section{Document Version:}

Publisher's PDF, also known as Version of Record (includes final page, issue and volume numbers)

\section{Please check the document version of this publication:}

- A submitted manuscript is the version of the article upon submission and before peer-review. There can be important differences between the submitted version and the official published version of record. People interested in the research are advised to contact the author for the final version of the publication, or visit the $\mathrm{DOI}$ to the publisher's website.

- The final author version and the galley proof are versions of the publication after peer review.

- The final published version features the final layout of the paper including the volume, issue and page numbers.

Link to publication

\section{General rights}

Copyright and moral rights for the publications made accessible in the public portal are retained by the authors and/or other copyright owners and it is a condition of accessing publications that users recognise and abide by the legal requirements associated with these rights.

- Users may download and print one copy of any publication from the public portal for the purpose of private study or research.

- You may not further distribute the material or use it for any profit-making activity or commercial gain

- You may freely distribute the URL identifying the publication in the public portal.

If the publication is distributed under the terms of Article 25fa of the Dutch Copyright Act, indicated by the "Taverne" license above, please follow below link for the End User Agreement:

www.tue.nl/taverne

Take down policy

If you believe that this document breaches copyright please contact us at:

openaccess@tue.nl

providing details and we will investigate your claim. 
J. C. REIJENGA*, W. VAN IERSEL, G. V. A. ABEN, Th. P. E. M. VERHEGGEN and F. M. EVERAERTS

Laboratory of Instrumental Analysis, University of Technology, P.O. Box 513, 5600 MB Eindhoven (The Netherlands)

\section{SUMMARY}

A method for conversion of the universal detector signal in isotachophoresis which enables the use of conventional chromatographic integration procedures is introduced. A microcomputer monitors the detector signal at $48 \mathrm{~Hz}$ with an 8-bit accuracy. The converted signal is stored in the computer memory and can be processed as if it were a chromatogram. The computer program was evaluated with a series of test mixtures and applied in the determination of anions in wine and urine.

\section{INTRODUCTION}

The application of isotachophoresis (ITP) in routine analysis is gaining in popularity. In 1982, for example, $58 \%$ of the papers published on ITP dealt with its application. The use of automatic signal processing equipment would be of great advantage in this respect.

For monitoring the UV signal in isotachophoresis a chromatographic approach $^{1,2}$ is commonly used and it will not be dealt with in this paper. The signal resolution obtained when using a universal detector has greatly improved since thermometric detection was replaced by a.c. conductivity (potential gradient) detection ${ }^{3-5}$. However, the nature of the universal detector signal precludes a chromatographic approach to signal processing. The amplitude of the signal does not give any quantitative information at all, whereas the time axis comprises both qualitative information (sequence of zones) and quantitative information (length of zones).

Methods to detect zone boundaries by means of the differential signal are widely used for measuring zone lengths manually. Attempts to use the differential signal for automatic processing have been made ${ }^{6}$, but the sensitivity of the method was rather critical, susceptible to interference and not unambiguous as the qualitative information is obscured in signals with a varying number of zones.

The only commercially available signal processor for isotachophoresis is in fact a modified chromatographic integrator (Type I-E1B; Shimadzu, Kyoto, Japan). This employs the differential of the isotachopherogram for the detection of zone transitions. Correct setting of the so-called wave-processing parameters is required 
in order to detect all zone transitions; failure would obscure the quantitative information. The dynamic range of this method enables accurate determination of relative step heights or potential unit values, ${ }^{3,5}$. In one analysis up to 50 zones can be measured. The sampling frequency of $10 \mathrm{~Hz}$ will be a limitation in measuring short zones. Other authors ${ }^{7,8}$ have also reported the use of signal-processing procedures. Storage of the complete isotachopherogram has obvious advantages, but requires much computer memory when sampling at $50 \mathrm{~Hz}$ and 8 bit.

$\mathrm{We}^{9,10}$ have introduced a signal-processing method for isotachophoresis, which applies a conversion to a signal with chromatographic properties and which is treated as such. The original isotachopherogram can be reconstructed from the converted signal which is stored in a small portion ( $1.3 \mathrm{kbytes})$ of the computer memory. The computer program, which is written in BASIC, can be used in any microprocessor with an 8-bit analog-to-digital convertor (ADC) and a 12-kbyte memory. The principle of the method is the conversion of the isotachopherogram (step height, $h, v s$. time, $t$ ) to a signal of amplitude, $\mathrm{d} t / \mathrm{d} h, v s$. step height $h$, as illustrated in Fig. 1.

\section{EXPERIMENTAL}

The isotachophoretic experiments were performed in equipment developed and built by Everaerts et al. ${ }^{3}$. The universal detector is an a.c. conductivity detector, 4 $\mathrm{kHz}, 10 \mu \mathrm{A}$, with two axially mounted $\mathrm{Pt} / \mathrm{Ir}(10 \%)$ electrodes, thickness $10 \mu \mathrm{m}$ and distance $0.1 \mathrm{~mm}$, in a $0.2 \mathrm{~mm} \mathrm{I.D.} \mathrm{cell,} \mathrm{unless} \mathrm{otherwise} \mathrm{indicated.} \mathrm{The} \mathrm{output} \mathrm{voltage}$

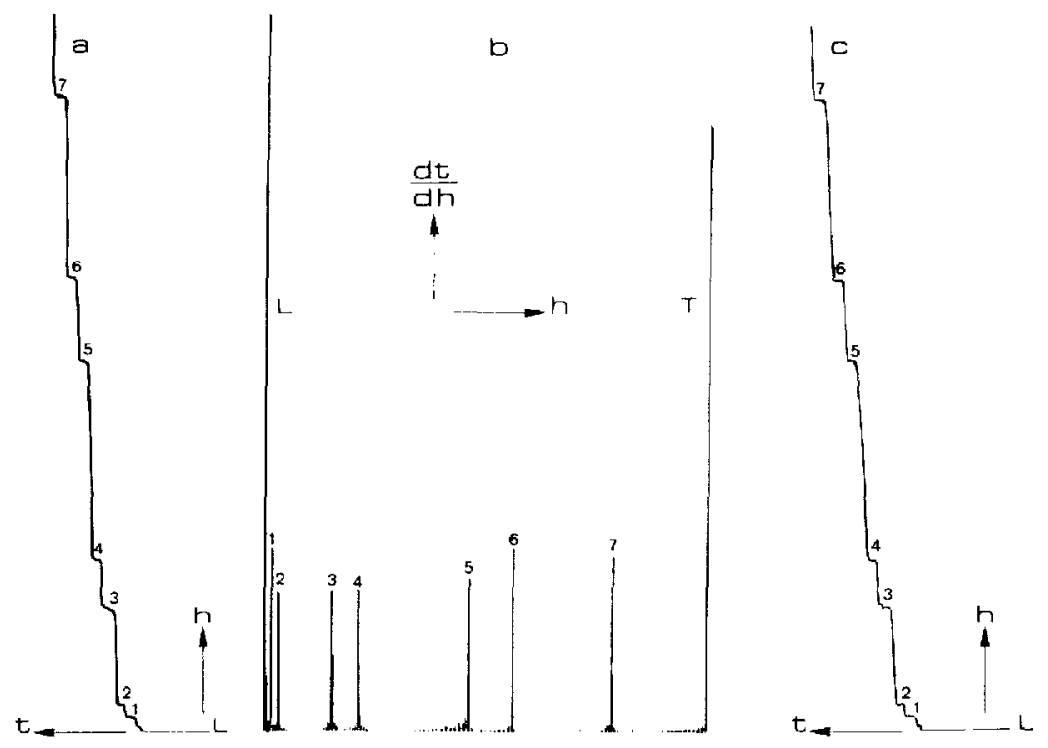

Fig. 1. The principle of signal conversion. a, The isotachopherogram of a standard mixture of chlorate (1), chromate (2), malonate (3), salicylate (4), gluconate (5), succinate (6) and acetate (7) (each 370 pmoles), analysed at $\mathrm{pH} 6$ (Table $\mathrm{I}$ ). $\mathrm{h}$, The converted signal showing peaks corresponding to the zones in the isotachopherogram. This can be interpreted as if it were a chromatogram which can be reconstructed (c) from the converted signal. $\mathrm{L}=$ Leading electrolyte; $\mathrm{T}=$ terminator. 
of the detector, which is directly proportional to the electric resistance of the cell, is corrected for the leading electrolyte conductivity and amplified to match the input level of the ADC.

The signal processing is achieved with a PUZZLE microprocessor (E. Steiner, Vienna, Austria). A digital casette recorder (Hans Knürr, München, F.R.G.) is used for program storage, a visual display terminal (Type ADM3A +; Lear Sigler, Anaheim, CA, U.S.A.) for interactive communication and both a graphic printer/plotter (IDS80; Integral Data System, Milford, MA, U.S.A.) and a potentiometric recorder (Kipp, Delft, The Netherlands) for registration. The microprocessor is equipped with two 12-bit ADCs and two 12-bit DACs and 23 kbytes of random access memory (RAM). The BASIC program was written specifically for the microcomputer used.

The reagents used for the operating systems and sample solutions were all of analytical reagent grade purity and obtained from either E. Merck (Darmstadt, F.R.G.) or Sigma (St. Louis, MO, U.S.A.). The operational systems are listed in Table I.

\section{RESULTS AND DISCUSSION}

For conversion of the isotachopherogram (step height, $h$, vs. time, $t$ ) to $\mathrm{d} t / \mathrm{d} h$ $v s$. $h$, the signal is digitized by the ADC. When measuring in 8-bit 256-step height intervals, $\mathrm{d} h$ can be distinguished. An array, $A \%$, of 256 elements in the computer program is declared: each time at 0.02 -sec intervals a step height is detected, the corresponding element in the array is incremented by one. The BASIC command for this operation is:

$$
H \%=\text { PEEK (37376): } A \%(H \%)=A \%(H \%)+1
$$

At the end of the analysis the number in each element $\mathrm{I}$ in the array, $A \%(I)$, is proportional to both the zone length $(\mathrm{d} t)$ in the corresponding step height interval $(\mathrm{d} h)$ and the sampling frequency. The latter determines the quantitative resolution. We have used $48 \mathrm{~Hz}$ in BASIC which is sufficiently high (accuracy $0.02 \mathrm{sec}$ ) with respect to the minimum detectable zone length. The latter is equal to the average residence time of the zone transition in the detector cell ${ }^{11}$. Typical values range from 0.3 to $3 \mathrm{sec}$, depending on the operating conditions. This means that, especially in

\section{TABLE I}

\section{OPERATIONAL SYSTEMS USED IN THE ISOTACHOPHORETIC EXPERIMENTS}

The driving current was $25 \mu \mathrm{A}$ unless otherwise indicated. PVA $=$ Poly(vinyl alcohol); HEC $=$ hydroxyethylcellulose.

\begin{tabular}{lll}
\hline & $p H 3.0$ & $p H 4.5$ \\
\hline Leading ion & Chloride & Chloride \\
Concentration & $0.01 M$ & $0.01 \mathrm{M}$ \\
Counter ion & $\beta$-Alanine & E-Aminocaproate \\
Additive & $0.05 \%$ PVA & $0.2 \%$ HEC \\
Terminating ion & $0.2 \%$ HEC & \\
& Propionate & Propionate \\
\hline
\end{tabular}


trace analysis, zone lengths approaching the theoretical minimal value can be measured quantitatively with sufficient resolution, e.g., $1 \%$ for a 2 -sec zone length ( $c a$. 0.2 nmole).

The quantitative accuracy in isotachophoresis with a well defined leading electrolyte transport number is determined only by the stability of the driving current and the accuracy with which the zone lengths are measured. With the method described it was found possible to take both these effects into account. If the microprocessor monitors the driving current and the detector signal simultaneously, the quantitative information is directly corrected for any slight drift in driving current. To achieve this, the driving current is sampled at 12 bit $(0.024 \%)$ and the detector signal at $27 \mathrm{~Hz}(0.037 \mathrm{sec})$. This means that for a zone length of $40 \mathrm{sec}$ an absolute accuracy of $0.1 \%$ can be achieved. A coulombmeter ${ }^{12,13}$ would be a useful alternative.

After a specific leading electrolyte/terminator system has been chosen (solvent, concentration, $\mathrm{pH}$, mobility, counter ion, additive), the qualitative resolution obtained is determined by the number of bits used in the ADC. We found that 8 bit $(0.4 \%$ resolution in step height) gave best results. A lower resolution will lead to an unacceptable loss of information, whereas a higher resolution may lead to inaccurate results, as the peaks in the converted signal will split up due to a possible slight drift of the step height, especially of longer zones. Furthermore, the peaks are not necessarily gaussian. For adequate resolution they need not be described by more than one data point. It should also be noted that the reproducibility of the detector response (step height) is usually not better than $1 \%$. This can be slightly improved by using relative step height (or potential unit) values, a reason why a $0.4 \%$ resolution was chosen. The data-reduction procedure used will normalize the results to 201 step-height intervals, so that a final qualitative resolution of $0.5 \%$ is obtained and up to 99 zones can theoretically be distinguished.

Some data reduction takes place in another respect, namely when an enforced $z^{2}$ e $^{3}$ visible by a so-called "back step" is detected, because time information is lost for this exception to the isotachophoretic steady-state sequence. Enforced zones are measured correctly but no distinction is made from "normal" zones of the same step height.

Fig. 1 shows an isotachopherogram ( $h$ vs. $t$ ) of a seven-component standard mixture (a), and the corresponding converted signal $\mathrm{d} t / \mathrm{d} h v s . h$ (b). The analysis was

TABLE II

REPRODUCIBILITY OF RELATIVE STEP HEIGHT (RSH) AND EFFECTIVE MOBILITY (M)

Four constituents in a standard mixture were analysed at $\mathrm{pH} 4.5$, measurements being made manually and with the computer program $(n=12)$.

\begin{tabular}{|c|c|c|c|c|c|c|}
\hline \multirow[t]{2}{*}{ Ion } & \multicolumn{2}{|c|}{ Manually } & \multicolumn{2}{|c|}{ Computer } & \multirow{2}{*}{$\begin{array}{l}10^{5} \cdot M \\
\left(\mathrm{~cm}^{2} V^{-1} \mathrm{sec}^{-1}\right)\end{array}$} & \multirow[t]{2}{*}{$S . D$} \\
\hline & $R S H$ & S.D. & $R S H$ & S.D. & & \\
\hline Oxalate & 0.133 & 0.001 & 0.133 & 0.002 & 49.0 & 0.2 \\
\hline Tartrate & 0.234 & 0.004 & 0.225 & 0.002 & 39.3 & 0.3 \\
\hline Phosphate & 0.306 & 0.003 & 0.304 & 0.003 & 33.5 & 0.2 \\
\hline Citrate & 0.406 & 0.003 & 0.406 & 0.003 & 28.2 & 0.2 \\
\hline
\end{tabular}




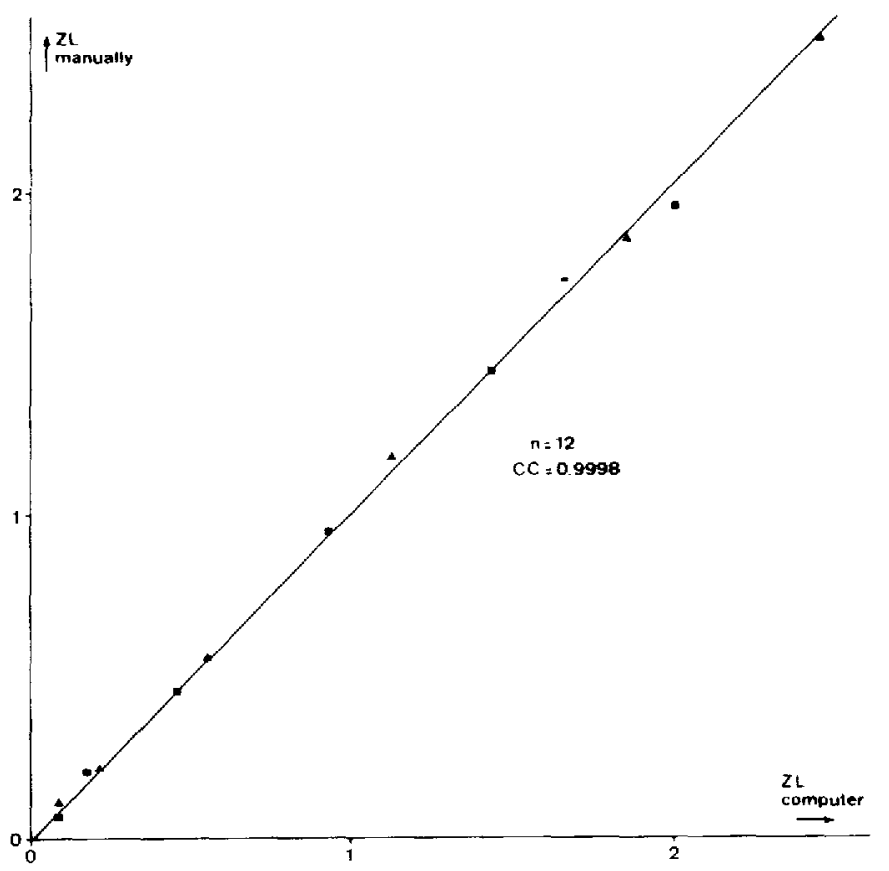

Fig. 2. The correlation of zonelengths (ZL) of oxalate $(\boldsymbol{C})$ and citrate $(\boldsymbol{A})$ relative to tartronate as an internal standard at $\mathrm{pH} 4.5$, measured manually and with the computer, in the range $0.5-8$ nmoles.

performed at $\mathrm{pH} 3.0$ (Table I). The area under the peaks is directly proportional to the sampling frequency and the length of the corresponding zone in the original isotachopherogram. From the converted signal a normal isotachopherogram can be reconstructed (Fig. 1c, where data reduction has taken placc).

The computer program is also provided with an integration procedure for the converted signal. The integration in this BASIC program lasts $c a .30 \mathrm{sec}$, which is sufficiently short with respect to the analysis time $(10-15 \mathrm{~min})$. It should also be mentioned that, upon detection of the terminator, the next analysis can be started immediately. Signal processing of that analysis will only have to start $c a$. $1 \mathrm{~min}$ before detection of the first zone transition. After integration, the results will yield, from leading electrolyte to terminating electrolyte: the zone number, the step height relative to that of the terminator, the length of the zone in units of $0.02 \mathrm{sec}$ and the effective mobility of the sample constituents.

Two facilities for selective data reduction are provided for in the program. The listing of the zone lengths can be limited to those zones having lengths exceeding a preset threshold value, comparable with a minimum area, as used in chromatographic integrators. The second possibility is to limit the results to those step heights corresponding to a discrete number of preset values, i.e., of the sample constituents of interest. Therefore a search window of $10 \%$ of the corresponding relative step height values is incorporated. Additional features of the program include a complete listing of the array, calculation of the total amount of ionic material migrating between the leading elecrolyte and terminator and calculation of the average mobility of all isotachophoretically migrating substances. In order to prevent the leading electrolyte 


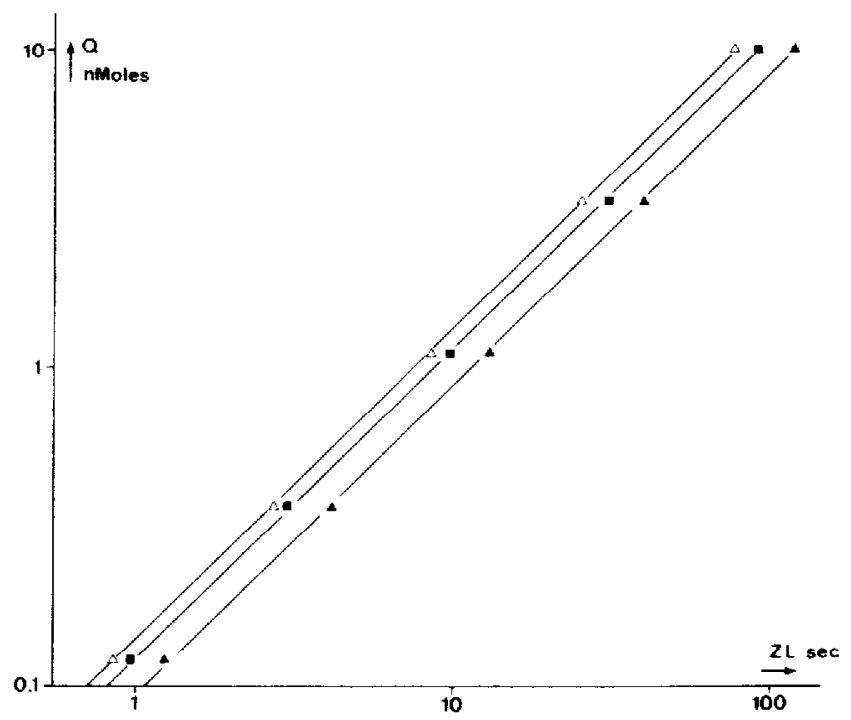

Fig. 3. The calibration graphs of chromate $(\Delta)$, salicylate $(\square)$ and succinate $(\Delta)$, at pH 4.5 in the range 0.1-10 nmoles, without the use of an internal standard, as calculated by the computer. $Q=Q u a n t i t y ; Z L$ $=$ zonelength.

and terminator zones from contributing to the last two calculations, only relative step heights between 0.03 and 0.97 are considered.

The computer program was first tested for accuracy, reproducibility and linearity by use of an electronic device which simulated an isotachophoretic analysis. Then a comparison was made between the relative step heights, mobilities and zone lengths determined experimentally and these calculated by the computer. In these isotachophoretic experiments a standard mixture was analyzed. The results, summarized in Table II, show a good reproducibility. The calibration graph (Fig. 2) was limited to injected amounts of 0.5-8 nmoles, because very short zone lengths cannot be measured accurately enough manually. A calibration graph over 2 decades covering the subnanomole level (Fig. 3) illustrates the linearity of the method just above the theoretical minimum detectable amount, $30^{\circ}$ pmoles in this case. Some of the converted isotachopherograms from which the calibration graph was constructed are shown in Fig. 4.

Depending on the relative sharpness of the zone boundaries, which will show differences from zone to zone, amounts approaching the minimum detectable amount can be quantified with sufficient signal-to-noise $(S / N)$ ratio, as is illustrated in Fig. 4d: the $\mathrm{S} / \mathrm{N}$ ratio is $c a .10$ in this example. With actual samples, higher noise or background levels in the converted signal may occur.

The analogy between a converted isotachopherogram and a chromatogram also extends to the "quality" of an analysis and properties such as "resolution". For example, isotachopherograms of analyses in a $0.5-\mathrm{mm}$ capillary show shorter zones and less sharp zone boundaries, compared with the $0.2-\mathrm{mm}$ capillary. This is caused by a more pronounced radial temperature profile due to the driving current, which also limits the current density ${ }^{14}$. The converted signal of these isotachopherograms 


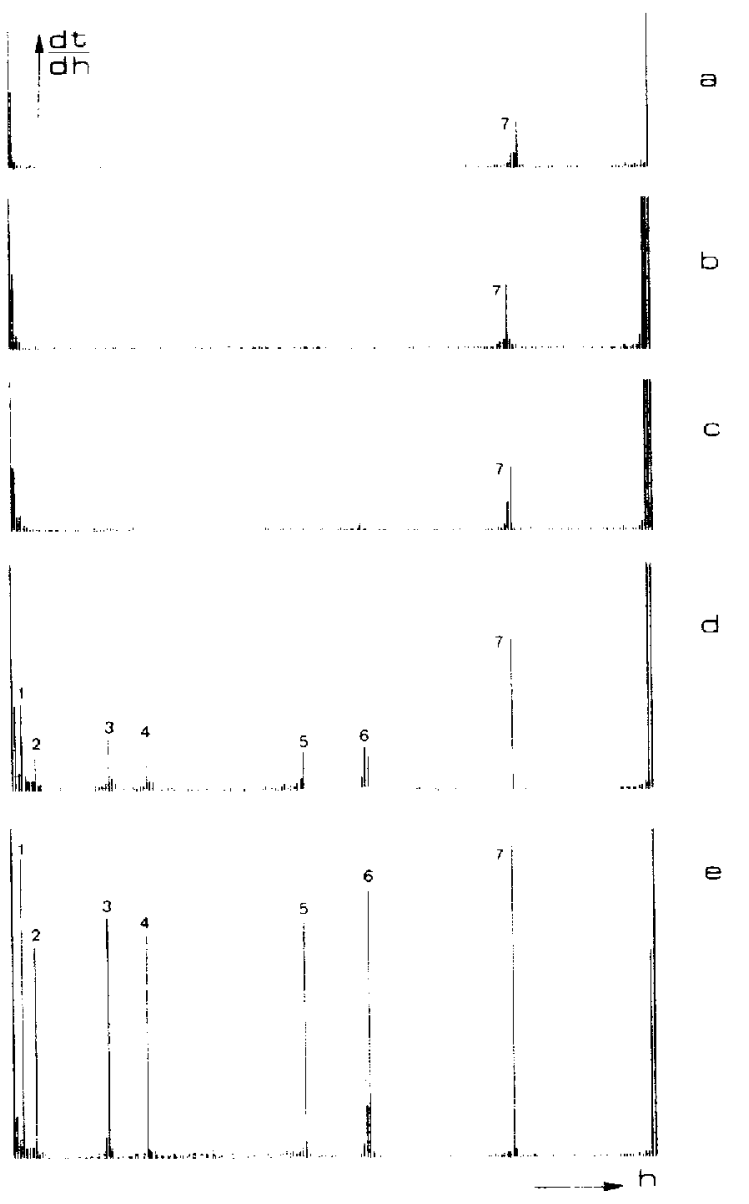

Fig. 4. Converted isotachopherograms of the analysis of increasing amounts of the standard mixture illustrated in Fig. 1. Acetate is present as an impurity in the electrolyte system (a). The amounts injected were 14 pmoles (b), 41 pmoles (c), 123 pmoles (d) and 370 pmoles (e).

shows peaks that are broader and less intense. At constant driving current and transport number, the peak area will of course be the same. This is analogous to a chromatogram from an analysis carried out in a column with decreased efficiency. Quantitative parameters such as resolution and quantitative parameters such as the signal-to-noise ratio can be applied to both signals. It should be borne in mind that the causes of poor performance are completely different, i.e., electroosmosis ${ }^{15}$ and a radial temperature profile ${ }^{14}$ in isotachophoresis and diffusion in chromatography.

The reproducibility of the signal-processing method is illustrated by the analysis of a sample of Greek Rosé wine under conditions described earlier ${ }^{16}$. The aim of the investigation was to analyse for additives such as sulphite and sorbate, and simultaneously determine a number of organic and inorganic acids for characterization. The phosphate and tartrate peaks in the corresponding converted signal are shown in Fig. 5. The phosphate/tartrate concentration ratio was ten; whereas their 


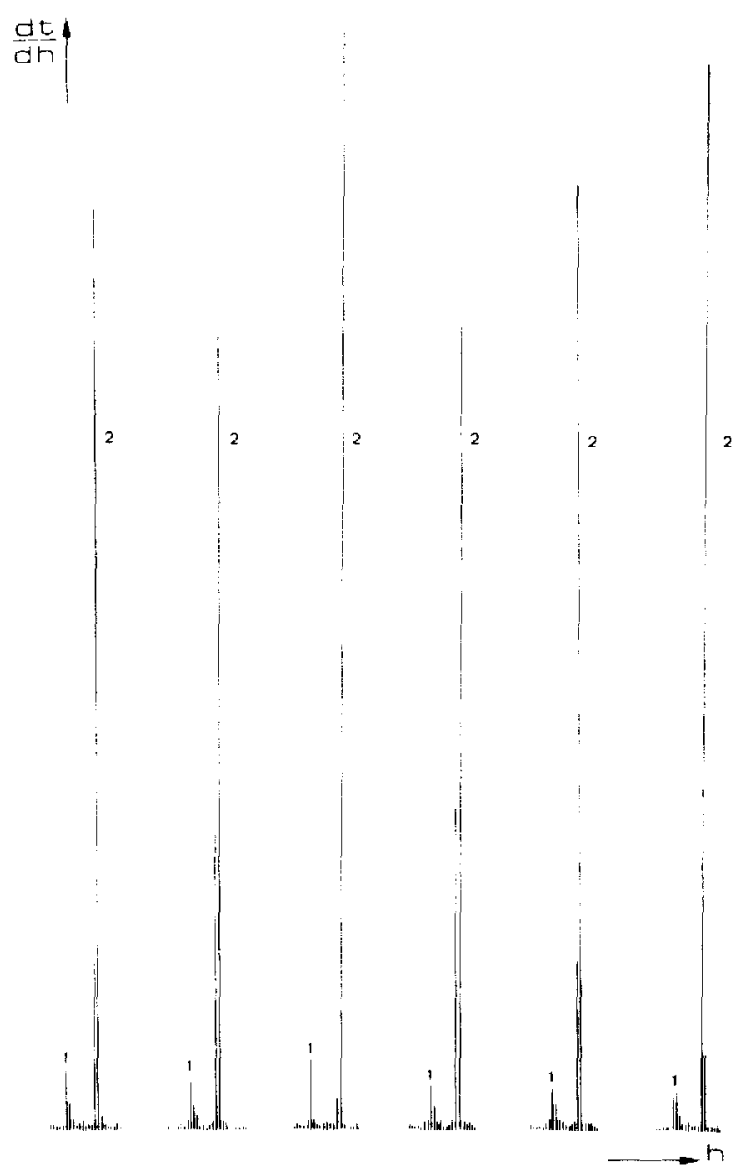

Fig. 5. Reproducibility of the determination of phosphate (1) and tartrate (2) in a wine sample at $\mathrm{pH} 2.9$.

relative step heights differed by $5 \%$. Integration of the peaks yielded results comparable to manual zone length measurements, both in terms of accuracy and precision. The zone lengths were $1.3 \pm 0.1 \mathrm{sec}$ for phosphate and $13.8 \pm 0.2 \mathrm{sec}$ for tartrate, and the relative step heights were $0.165 \pm 1 \%$ and $0.210 \pm 2 \%$ respectively. It was not necessary to use an internal standard.

Fig. 6 shows the analysis of human urine at pH 4.5 (Table I), in which oxalate, citrate, glycolate and phosphate were determined. This analysis was part of an investigation into the metabolism of oxalate and glycolate in different types of oxaluria. The dynamic range that can be achieved is illustrated by the fact that both oxalate and phosphate, although off-scale, can be determined quantitatively under the conditions described. Moreover, Fig. 6 shows that zone transitions near the terminator are less sharp (and consequently the peaks are broader) because the electroosmotic counter-flow increases with field strength and $\mathrm{pH}^{15}$. 


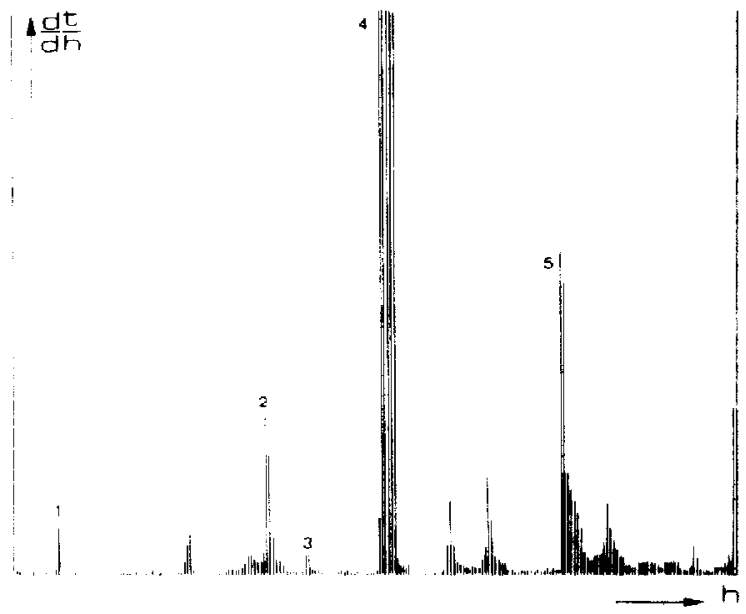

Fig. 6. Converted isotachopherograms of the analysis of $0.5 \mu$ l human urine. Oxalate (1), citrate (2), glycolate (3), phosphate (4) and acetate (5) were analysed at $\mathrm{pH} 4.5^{10}$.

\section{CONCLUSIONS}

The advantages of the signal-processing method described are obvious. With a relatively small computer memory the results of an entire isotachophoretic analysis can be stored and the original isotachopherogram can be reconstructed if necessary. A minimum requirement for this method is an 8-bit ADC and 12 kbyte of RAM. The converted signal can either be processed by use of the program itself or integrated by any chromatographic signal-processing system. Ultimately, the high accuracy, precision and speed of computerized signal processing will broaden the application of isotachophoresis in routine analysis.

\section{REFERENCES}

1 L. Arlinger, J. Chromatogr., 91 (1974) 785.

2 J. P. M. Wielders, Thesis, Eindhoven University of Technology, Eindhoven, The Netherlands, 1978.

3 F. M. Everaerts, J. L. Beckers and Th. P. E. M. Verheggen, Isotachophoresis, Theory, Instrumentation and Applications (Journal of Chromatography Library, Vol. 6), Elsevier, Amsterdam, Oxford, New York, 1976.

4 S. Stankoviansky, P. Cičmanec and D. Kaniansky, J. Chromatogr., 106 (1975) 131.

5 J. Akiyama and T. Mizuno, J. Chromatogr., 119 (1976) 605.

6 A. J. Mulder and J. Zuska, J. Chromatogr., 91 (1974) 819-822.

7 J. Lang and B. Büchele, in F. M. Everaerts (Editor), Analytical Isotachophoresis (Analytical Chemistry Symposia Series, Vol. 6), Elsevier, Amsterdam, Oxford, New York, 1981, p. 75.

8 F. S. Stover, K. L. Depperman, W. A. G. Grote and W. E. Dahl, in C. J. Holloway (Editor), Proc. 3rd Int. Symp. Isotachophoresis, Goslar, June 1-4, 1982, in preparation.

9 J. C. Reijenga and D. M. J. Kroonenberg, in F. M. Everaerts (Editor), Analytical Isotachophoresis (Analytical Chemistry Symposia Series, Vol. 6), Elsevier, Amsterdam, Oxford, New York, 1981, p. 217.

10 J. C. Reijenga and W. van Iersel, in C. J. Holloway (Editor), Proc. 3rd Int. Symp. Isotachophoresis, Goslar, June $1-4,198$ ?, in preparation.

11 J. C. Reijenga, F. M. Everaerts and Th. P. E. M. Verheggen in C. J. Holloway (Editor), Proc. 3 rd Int. Symp. Isotachophoresis, Goslar, June 1-4, 1982, in preparation. 
12 M. Deml, J. Pospichal and P. Botek, in C. J. Holloway (Editor), Proc. 3rd Int. Symp. Isotachophoresis, Goslar, June 1-4, 1982, in preparation.

13 H. Verhoeven, Graduation report, University of Technology, Eindhoven, The Netherlands, 1983.

14 Th. P. E. M. Verheggen, F. E. P. Mikkers and F. M. Everaerts, J. Chromatogr., 132 (1977) 205-215.

15 J. C. Reijenga, G. V. A. Aben, Th. P. E. M. Verheggen and F. M. Everaerts, J. Chromatogr., 260 (1983) $241-254$.

16 J. C. Reijenga, Th. P. E. M. Verheggen and F. M. Everaerts, J. Chromatogr., 245 (1982) 120. 